\title{
Seroprevalence of SARS-CoV-2 infection in a municipality in southern Brazil
}

\author{
Soroprevalência da infecção por SARS-CoV-2 em um município do sul do Brasil \\ Seroprevalencia de la infección por SARS-CoV-2 en un municipio del sur de Brasil
}

Received: 07/07/2021 | Reviewed: 07/15/2021 | Accept: 07/19/2021 | Published: 07/26/2021

Maria Joana Carvalho e Silva

ORCID: https://orcid.org/0000-0003-4993-0375 Federal University of Fronteira Sul, Brazil

E-mail: mariajoanacarvalho@hotmail.com

Kassia Kramer

ORCID: https://orcid.org/0000-0002-9263-921X

Federal University of Fronteira Sul, Brazil

E-mail: kassiakramer94@gmail.com

Yasmim Paula Cesco

ORCID: https://orcid.org/0000-0003-3693-5273

Federal University of Fronteira Sul, Brazil

E-mail: yasmimpaulacesco@gmail.com

Kendy Otak

ORCID: https://orcid.org/0000-0003-4069-699X

Community University of Chapecó Region, Brazil

E-mail: kendyotak@gmail.com

Andréia Machado Cardoso

ORCID: https://orcid.org/0000-0003-4243-8855

Federal University of Fronteira Sul, Brazil

E-mail: andreia.cardoso@uffs.edu.br

Grasiela Marcon

ORCID: https://orcid.org/0000-0001-5151-4640

Federal University of Fronteira Sul, Brazil

E-mail: grasiela.marcon@uffs.edu.br

Camila Cassol Brum

ORCID: https://orcid.org/0000-0003-0947-1880

Western Regional Hospital, Brazil

E-mail: camilacabr@yahoo.com.br

Diego Leonardo Bet

ORCID: https://orcid.org/0000-0002-7548-4797

Dermatological Clinic Bet, Brazil

E-mail: diegolbet@gmail.com

Adriana Wagner

ORCID: https://orcid.org/0000-0002-4524-9999

Federal University of Fronteira Sul, Brazil

E-mail: adriana.wagner@uffs.edu.br

Gabriela Marcolin

ORCID: https://orcid.org/0000-0001-5602-1079

Chapecó Health Department, Brazil

E-mail: gmarcolin87@gmail.com

Junir Antônio Lutinski

ORCID: https://orcid.org/0000-0003-0149-5415

Community University of Chapecó Region, Brazil

E-mail: junir@unochapeco.edu.br

\begin{abstract}
SARS-CoV-2 is an RNA virus, responsible for causing an acute respiratory syndrome, which became known worldwide for its rapid spread and for causing the pandemic of a new disease: COVID-19. Thus, epidemiological studies have been developed in order to determine the extent of the problems and the magnitude of the disease. The present study aimed to evaluate the seroprevalence of SARS-CoV-2 infection and its relationship with sociodemographic and clinical-epidemiological factors in the city of Chapecó, Santa Catarina, Brazil. It was a quantitative, epidemiological, observational, cross-sectional, population-based study with 2179 participants. Socio-demographic, associated behavioral, aggravating and comorbid parameters were evaluated, relating them to positivity or not in the rapid test implemented. The rapid test identified 22.2\% of the diagnosed seroprevalence of COVID-19 in the municipality in question. A higher incidence of cases was observed in people living with other people, in people who had contact with positive cases, and in symptomatic patients, corroborating with current studies. The results highlight the importance of clinical-epidemiological studies for the understanding and control of COVID-19.
\end{abstract}


Keywords: Coronavirus infections; Epidemiology; Severe acute respiratory syndrome.

\section{Resumo}

O SARS-CoV-2 é um vírus RNA, responsável por causar uma síndrome respiratória aguda, que se tornou mundialmente conhecido por sua rápida disseminação e por causar a pandemia de uma nova doença: COVID-19. Assim, estudos epidemiológicos têm sido desenvolvidos a fim de determinar a extensão dos problemas e a magnitude da doença. O presente estudo teve como objetivo avaliar a soroprevalência da infecção pelo SARS-CoV-2 e sua relação com fatores sociodemográficos e clínico-epidemiológicos na cidade de Chapecó, Santa Catarina, Brasil. Tratase de um estudo quantitativo, epidemiológico, observacional, transversal, de base populacional, com 2.179 participantes. Foram avaliados parâmetros sociodemográficos, comportamentais associados, agravantes e comórbidades, relacionando-os com a positividade ou não no teste rápido implementado. $\mathrm{O}$ teste rápido identificou 22,2\% das soroprevalências do COVID-19 diagnosticadas no município em questão. A maior incidência de casos foi observada em pessoas que conviviam com outras pessoas, naquelas que tiveram contato com casos positivos e em pacientes sintomáticos, corroborando com estudos atuais. Os resultados evidenciam a importância dos estudos clínicoepidemiológicos para a compreensão e controle do COVID-19.

Palavras-chave: Infecções por coronavírus; Epidemiologia; Síndrome respiratória aguda grave.

\section{Resumen}

El SARS-CoV-2 es un virus RNA, responsable de provocar una síndrome respiratoria aguda, que se hizo conocido mundialmente por su rápida propagación y por provocar la pandemia de una nueva enfermedad: COVID-19. Así, se han desarrollado estudios epidemiológicos con el fin de determinar la extensión de los problemas y la magnitud de la enfermedad. El presente estudio tuvo como objetivo evaluar la seroprevalencia de la infección por SARS-CoV-2 y su relación con factores sociodemográficos y clínico-epidemiológicos en la ciudad de Chapecó, Santa Catarina, Brasil. Fue un estudio poblacional cuantitativo, epidemiológico, observacional, transversal, con 2179 participantes. Se evaluaron parámetros sociodemográficos, conductuales asociados, agravantes y comorbidades, relacionándolos con positividad o no en la prueba rápida implementada. La prueba rápida identificó el $22,2 \%$ de las seroprevalencias de COVID-19 diagnosticadas en el municipio en cuestión. Se observó una mayor incidencia de casos en personas que conviven con otras personas, en personas que tuvieron contacto con casos positivos y en pacientes sintomáticos, corroborando con estudios actuales. Los resultados resaltan la importancia de los estudios clínico-epidemiológicos para la comprensión y el control de COVID-19.

Palabras clave: Infecciones por coronavirus; Epidemiología; Síndrome respiratorio agudo severo.

\section{Introduction}

In March 2020, the World Health Organization (WHO) recognized COVID-19 (Corona Virus Disease) as a pandemic. Since then, investigations on the subject have emerged worldwide, ranging from epidemiological studies, prevention, treatment and the search for immunizers (WHO, 2020). Epidemiological studies allow preventive efforts to be directed by making it possible to determine the extent of the occurrence of diseases and by offering a descriptive overview of the magnitude of how diseases are distributed, in this case COVID-19 (Petry, 2020).

The strategies adopted by each country in the face of the pandemic depend on the country's health system, governmental and socio-demographic characteristics (Bambra et al., 2020; Carvalho, Lima \& Coeli, 2020). In Brazil, a country with a universal health system, where the conditions of climate, population density and social dynamics are heterogeneous, it is essential to consider reality with the data collected locally to guide actions that have greater impact and fewer costs.

Chapecó is a municipality in the south of Brazil that has an estimated population of 224 thousand people and provides health services to a region that comprises more than one million inhabitants. It has become a regional reference in the treatment of needs related to infection with the new coronavirus.

In view of this context, it is known the importance of notifications of suspected cases for active search and epidemiological monitoring, especially to assess the progression of the epidemic. Thus, the present study aimed to assess the seroprevalence of SARS-CoV-2 infection and its relationship with socio-demographic and clinical-epidemiological factors in the city of Chapecó, Santa Catarina. 


\section{Methodology}

\subsection{Study design and sampling}

This was an epidemiological, observational, cross-sectional population-based (Koche, 2011; Ludke \& Andre, 2013; Yin, 2015) study carried out in the municipality of Chapecó, Santa Catarina, Brazil. Its application took place after approval by the Human Research Ethics Committee under opinion no. 4,074,596.

The sample was calculated from the population estimate of the municipality of Chapecó for the year 2020. The EpInfo application was used, with $95 \%$ reliability, a margin of error of $2 \%$ and a greater heterogeneity scenario, taking into consideration the proportionality regarding gender and age groups. Based on these criteria, 2,310 participants were gathered. This number was selected at random and the entire data collection process lasted eight weeks. The sample distribution in the different regions of the municipality is shown in Figure 1.

Figure 1 - Distribution of the sample in the municipality of Chapecó, SC, June, July and August 2020.

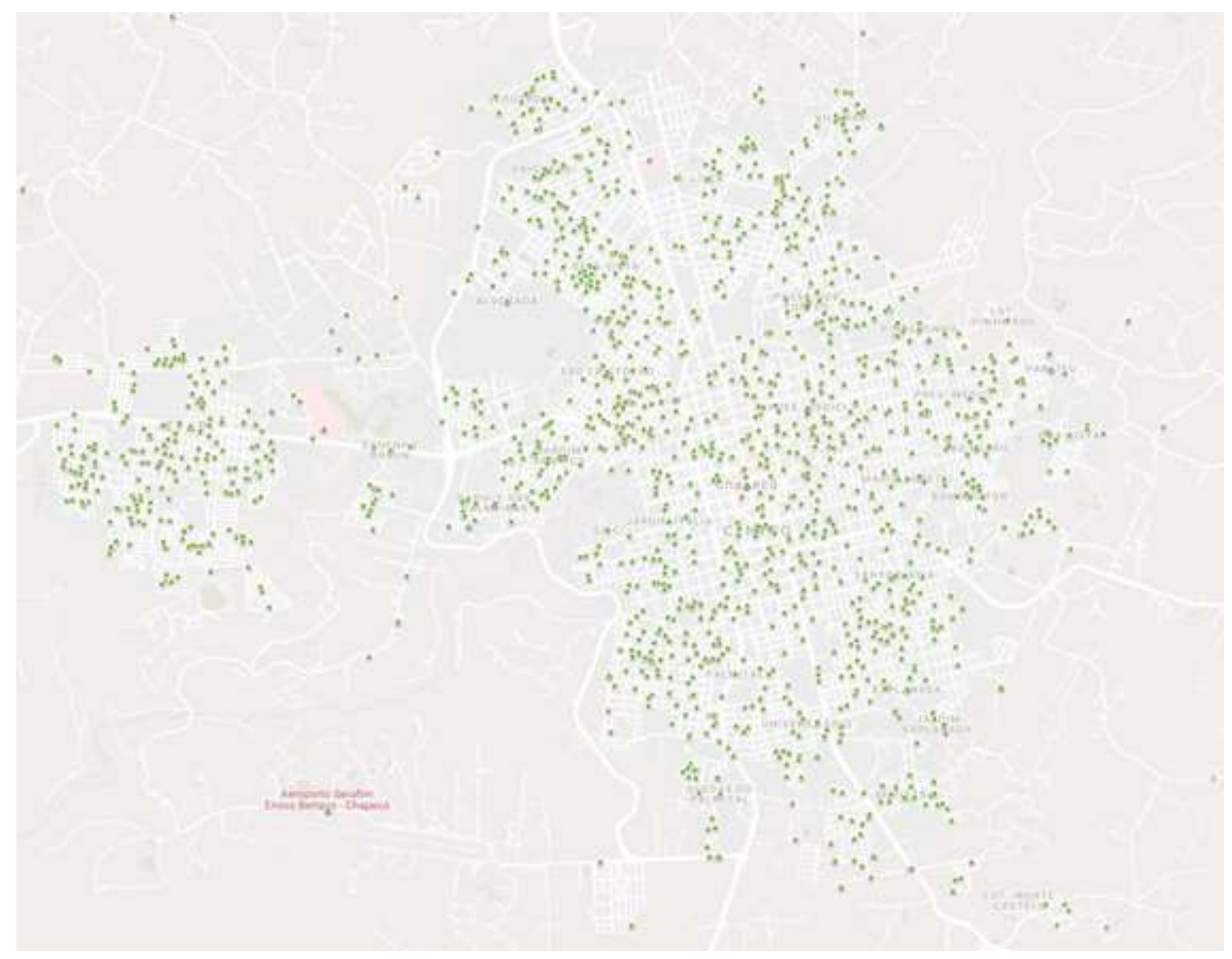

Source: Authors (2021).

All the individuals who were included in the study, regardless of sex, age, ethnicity or religion, had an identification number in the municipality's health register and agreed to participate through the Free and Informed Consent Form (ICF). In the case of participants under 18 years of age, the parents or legal guardians authorized the participation through a specific ICF for parents and guardians.

All those who refused to participate or those who did not allow the recording of verbal consent from the IC were excluded. In addition, after three consecutive attempts to contact each other on different shifts, those who did not answer the 
call were excluded and replaced by subsequent ones. Also excluded were those who did not have updated telephone contact or those who no longer lived in the municipality of Chapecó-SC.

\subsection{Data collection and rapid test}

Based on the municipality's database, individuals were stratified according to sex and age groups and, afterwards, chosen randomly. The proportional draw of the sample for each stratum was carried out by searching for the participant's registration in the municipal identification system in order to obtain telephone contact information. From this, an attempt was made to contact them to verify their interest in participating in the research. If positive, the reading of the informed consent and the verbal acceptance of it was followed to apply a socio-demographic and clinical-epidemiological questionnaire. The entire conversation was recorded, following a previously established protocol of questions, which could be adapted to the needs of each telephone contact as the researcher found communication with the participant more effective and efficient.

Then, the rapid test for the detection of antibodies to SARS-COV-2 in a field clinic was offered to be scheduled in the same week. Contact through telephone was made in the months of June, July and August 2020, from Monday to Monday, between 7 am and $10 \mathrm{pm}$, by teams of academics from health courses at the Federal University of Fronteira Sul, Chapecó campus and the Community University from Chapecó, Unochapecó, previously trained.

The rapid test used was the ONE STEP COVID-2019 TEST® (manufacturer Guangzhou Wondfo Biotech Co. I representative Celer Biotecnologia S/A), which has $86 \%$ sensitivity and 99\% specificity, if applied in the manner and within the time period established by the package instructions. The tests were provided by the city hall of Chapecó.

For its application, asepsis of the participant's fingertip was performed, and a drop of blood was collected and, with the aid of a pipette, the biological material was placed in the determined cavity of the test device, and then the diluent buffer was added. The recommended time of wait of 20 to 30 minutes was obeyed, which was immediately informed to the participant. These procedures followed the instructions on the test package insert and the recommendations from the Ministry of Health.

Health professionals in the municipality, who received specific training for this procedure, carried out the collection and application of the rapid test. It is important to highlight that the health professional responsible for the test was responsible for directing the medical care of all participants whose rapid tests were positive. In addition, the data obtained at each stage were presented to municipal managers, especially for notification via health surveillance.

\subsection{Data analysis}

The data were tabulated using the Google spreadsheets software. The variables were analyzed for frequencies using the mean as a measure of central tendency and the standard deviation as a measure of dispersion. The distribution of quantitative data was tested by the Shapiro-Wilk test and the Mann-Whitney (U) non-parametric test was used to compare groups. The Chi-square test was used to verify associations between qualitative variables. The frequency of positive cases in the rapid test was used as a dependent variable. The tests were performed with the aid of the Statistical Package for the Social Sciences (SPSS), v. 22. The prevalence (rate per 100,000) was also calculated. Statistical significance was adopted at $\mathrm{p}<0.05$.

\section{Results}

A total of 2,179 people participated in the study. Of these, 14 had a positive rapid test for COVID-19, with a similar prevalence among men and women. 
The average seroprevalence found by the rapid test in testing was lower than the seroprevalence already known by the municipal health network in the same period. The index found by the rapid test was able to identify only $22.2 \%$ of seroprevalence already diagnosed with COVID-19 in the municipality of Chapecó (Figure 2).

Figure 2 - Average incidence observed by the health service and tested by the rapid test in the municipality of Chapecó, SC, June, July and August 2020. Vertical bars indicate the standard deviation.

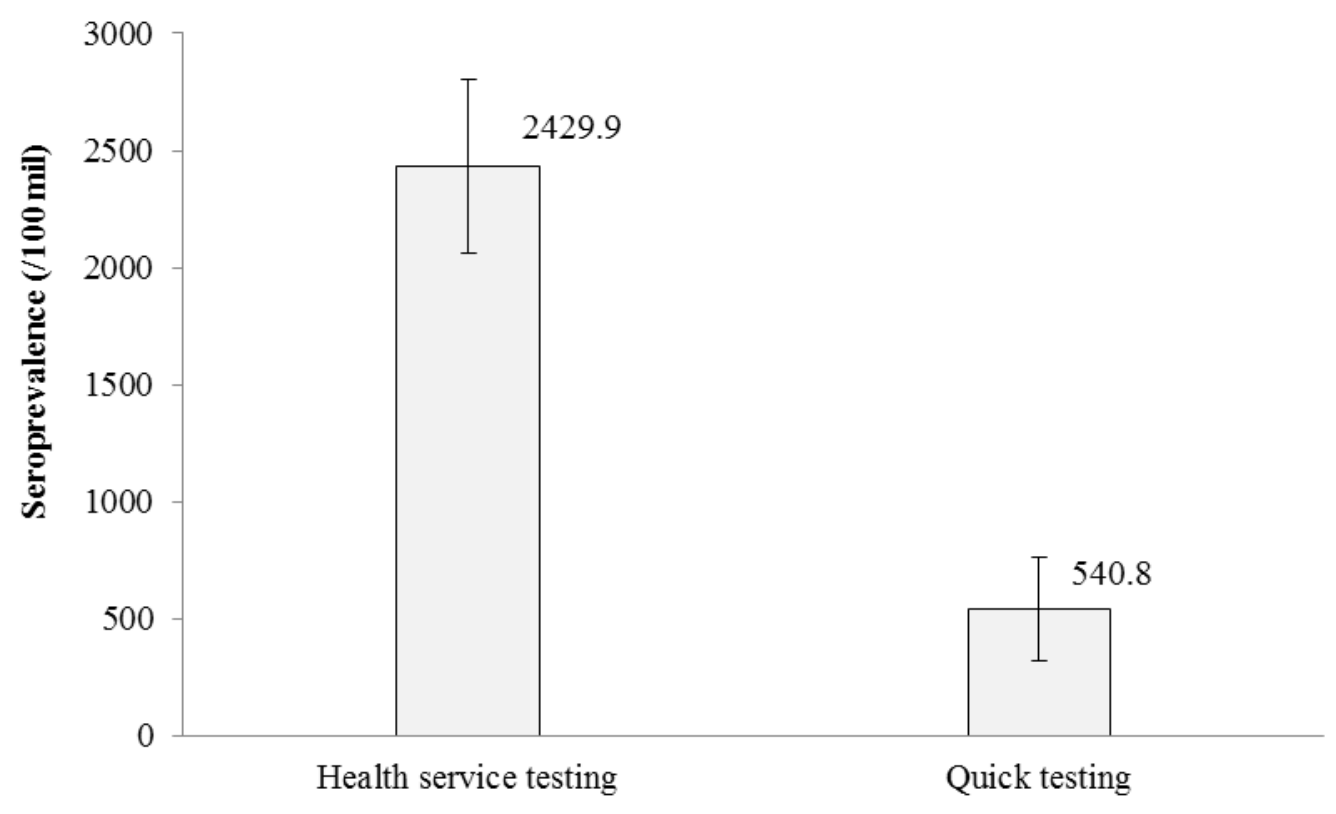

Source: Authors (2021).

The study showed a statistically significant association $(\mathrm{p}<0.001)$ between the number of people living with it and positive cases. Participants living with five or more people had a higher prevalence of positive rapid test for COVID-19, which was significantly higher than the other conditions (Table 1).

In families with three or more children, there was a higher prevalence of positive cases. As for education, there was a higher incidence in those participants with incomplete higher education and in those with postgraduate degrees. Among the participants who work with a formal contract, there was more than twice the incidence of positive cases when compared to workers without a formal contract. In health professionals or students, the incidence was more than double that found in the rest of the population (Table 1). 
Research, Society and Development, v. 10, n. 9, e30710917996, 2021

(CC BY 4.0) | ISSN 2525-3409 | DOI: http://dx.doi.org/10.33448/rsd-v10i9.17996

Table 1 - Socio-demographic description, comparison and associations based on the positive cases of the rapid test for COVID 19, in the municipality of Chapecó, SC, June, July and August 2020.

\begin{tabular}{|c|c|c|c|c|}
\hline Participants profile & Count (n) & Mean & $\begin{array}{l}\text { Standard } \\
\text { Deviation }\end{array}$ & Statistical Significance \\
\hline \multicolumn{5}{|l|}{ Age (years) } \\
\hline Positives & 14 & 33,6 & 18.4 & \multirow[t]{2}{*}{$\begin{array}{l}\mathrm{U}=14822 \\
\mathrm{p}=0.88\end{array}$} \\
\hline Negatives & 2165 & 33,3 & 19.1 & \\
\hline \multicolumn{5}{|l|}{ Income $(\mathrm{R} \$)$} \\
\hline Positive & & 5350,00 & 2728.7 & \multirow[t]{2}{*}{$\begin{array}{l}\mathrm{U}=3804 \\
\mathrm{p}=0.36\end{array}$} \\
\hline Negative & & 4311,00 & 6565.0 & \\
\hline Profile & Cont (n) & Positive & $\begin{array}{l}\text { Prevalence }(/ 100 \\
\text { thousand) }\end{array}$ & Significance (Chi-square) \\
\hline \multicolumn{5}{|l|}{ Sex } \\
\hline Female & 1053 & 7 & 664.8 & \multirow[t]{2}{*}{$\mathrm{p}=0.89$} \\
\hline Male & 1126 & 7 & 621.7 & \\
\hline \multicolumn{5}{|l|}{ Skin Color } \\
\hline Yellow & 28 & 0 & 0.0 & \multirow[t]{5}{*}{$\mathrm{p}=0.97$} \\
\hline White & 1731 & 11 & 635.5 & \\
\hline Indigen & 2 & 0 & 0.0 & \\
\hline Black & 28 & 0 & 0.0 & \\
\hline Brown & 390 & 3 & 769.2 & \\
\hline \multicolumn{5}{|l|}{ Marital status } \\
\hline With partner & 1010 & 6 & 594.1 & \multirow[t]{2}{*}{$\mathrm{p}=0.79$} \\
\hline Without partner & 1169 & 8 & 684.3 & \\
\hline \multicolumn{5}{|l|}{ Number of children } \\
\hline None & 1059 & 7 & 661.0 & \multirow[t]{4}{*}{$\mathrm{p}=0.94$} \\
\hline One & 418 & 3 & 717.7 & \\
\hline Two & 446 & 2 & 448.4 & \\
\hline Three or more & 256 & 2 & 781.3 & \\
\hline \multicolumn{5}{|c|}{ Number of people that lives with } \\
\hline One & 134 & 2 & 1492.5 & \multirow[t]{5}{*}{$\mathrm{p}<0.001$} \\
\hline Two & 425 & 3 & 705.9 & \\
\hline Three & 682 & 2 & 293.3 & \\
\hline Four & 641 & 0 & 0.0 & \\
\hline Five or more & 297 & 7 & 2356.9 & \\
\hline
\end{tabular}


Number of elderly people that lives with

$\begin{array}{lllll}\text { None } & 1707 & 11 & 644.4 & \mathrm{p}=0.62 \\ \text { One } & 296 & 3 & 1013.5 & 0.0 \\ \text { Two } & 162 & 0 & 0.0 \\ \text { Tree or more } & 14 & 0 & \end{array}$

\begin{tabular}{|c|c|c|c|c|}
\hline \multicolumn{5}{|l|}{ Education } \\
\hline Incomplete primary school & 609 & 4 & 656.8 & $\mathrm{p}=0.17$ \\
\hline Complete primary school & 140 & 0 & 0.0 & \\
\hline Incomplete high school & 201 & 1 & 497.5 & \\
\hline Complete high school & 500 & 3 & 600.0 & \\
\hline Incomplete graduation & 248 & 4 & 1612.9 & \\
\hline Complete graduation & 364 & 0 & 0.0 & \\
\hline Post-Graduation & 117 & 2 & 1709.4 & \\
\hline \multicolumn{5}{|c|}{ Formal Work } \\
\hline Yes & 738 & 8 & 1084.0 & $\mathrm{p}=0.06$ \\
\hline No & 1441 & 6 & 416.4 & \\
\hline \multicolumn{5}{|c|}{ Private health service } \\
\hline yes & 600 & 3 & 500.0 & $\mathrm{p}=0.60$ \\
\hline No & 1579 & 11 & 696.6 & \\
\hline \multicolumn{5}{|l|}{ Health professional or student } \\
\hline Yes & 136 & 2 & 1470.6 & $\mathrm{p}=0.21$ \\
\hline No & 2043 & 12 & 587.4 & \\
\hline \multicolumn{5}{|c|}{ Work or intern with health professionals or patients } \\
\hline Yes & 140 & 1 & 714.3 & $\mathrm{p}=0.91$ \\
\hline No & 2039 & 13 & 637.6 & \\
\hline
\end{tabular}

Source: Authors (2021).

Statistical significance was found in the association between positive cases and becoming ill since the beginning of the pandemic ( $\mathrm{p}<0.001)$, having contact with a sick person in the last two weeks $(\mathrm{p}=0.01)$ and having or having previously been diagnosed with COVID- 19 ( $\mathrm{p}<0.001$ ). The incidence of positive cases in the participants who reported having experienced any of the symptoms of COVID-19 was greater than five times the asymptomatic population. Having had contact with a sick person in the past two weeks has increased the number of positive rapid tests more than three times. Finally, having a previous diagnosis of COVID-19 brought a fourteen times higher incidence of positive results in the rapid test of this research (Table 2).

The incidence of positive cases in participants with someone in their home environment who was ill or who was already ill was almost double that found in participants with healthy home contacts. In addition, the incidence of positive rapid 
tests was higher in those who traveled in the last two weeks before the questionnaire was administered. Finally, the frequency of positive tests in those who continued studying or working outside the home was higher, as well as in those who left their homes to practice physical exercises (Table 2).

Table 2 - Evaluation of associated behavioral factors and associations based on the positive cases of the rapid test for COVID 19, in the municipality of Chapecó, SC, June, July and August 2020.

\begin{tabular}{|c|c|c|c|c|}
\hline Profile & Count (n) & Positives & $\begin{array}{l}\text { Prevalence }(/ 100 \\
\text { thousand) }\end{array}$ & $\begin{array}{l}\text { Significance (Chi- } \\
\text { square) }\end{array}$ \\
\hline \multicolumn{5}{|l|}{ Sick } \\
\hline yes & 107 & 1 & 934.6 & $\mathrm{p}=0.69$ \\
\hline No & 2072 & 13 & 627.4 & \\
\hline \multicolumn{5}{|c|}{ Have been sick since the pandemic beginning } \\
\hline Yes & 423 & 8 & 1891.3 & $\mathrm{p}<0.001$ \\
\hline No & 1756 & 6 & 341.7 & \\
\hline \multicolumn{5}{|c|}{ Someone in the community is or has been sick } \\
\hline Yes & 386 & 4 & 1036.3 & $\mathrm{p}=0.28$ \\
\hline No & 1793 & 10 & 557.7 & \\
\hline \multicolumn{5}{|c|}{ Had contact with sick person in the last two weeks } \\
\hline Yes & 284 & 5 & 1760.6 & $\mathrm{p}=0.01$ \\
\hline No & 1895 & 9 & 474.9 & \\
\hline \multicolumn{5}{|c|}{ Traveled in the last two weeks } \\
\hline Yes & 301 & 3 & 996.7 & $\mathrm{p}=0.41$ \\
\hline No & 1878 & 11 & 585.7 & \\
\hline \multicolumn{5}{|c|}{ Took flu shot in 2020} \\
\hline Yes & 972 & 5 & 514.4 & $\mathrm{p}=0,50$ \\
\hline No & 1207 & 9 & 745.7 & \\
\hline \multicolumn{5}{|c|}{ Had or are diagnosed with COVID 19} \\
\hline Yes & 24 & 2 & 8333.3 & $\mathrm{p}<0.001$ \\
\hline No & 2155 & 12 & 556.8 & \\
\hline \multicolumn{5}{|c|}{ Continued studying or working during the pandemic period } \\
\hline Yes & 1322 & 10 & 756.4 & $\mathrm{p}=0.41$ \\
\hline No & 857 & 4 & 466.7 & \\
\hline \multicolumn{5}{|c|}{ Studied or worked outside the home during the pandemic period } \\
\hline Yes & 1107 & 8 & 722.7 & $\mathrm{p}=0.63$ \\
\hline No & 1072 & 6 & 559.7 & \\
\hline
\end{tabular}


Go out to do physical exercises

\begin{tabular}{|c|c|c|c|c|}
\hline Yes & 600 & 5 & 833.3 & $\mathrm{p}=0.49$ \\
\hline No & 1579 & 9 & 570.0 & \\
\hline
\end{tabular}

Left home in the last 15 days

\begin{tabular}{lccc} 
Yes & 1864 & 12 & $\mathrm{p}=0.98$ \\
No & 315 & 2 & 643.8 \\
\hline
\end{tabular}

Someone, besides the residents, frequents the home

\begin{tabular}{|c|c|c|c|c|}
\hline Yes & 837 & 4 & 477.9 & $\mathrm{p}=0.45$ \\
\hline No & 1342 & 10 & 745.2 & \\
\hline
\end{tabular}

Have been in any health service in the last month

\begin{tabular}{|c|c|c|c|c|}
\hline Yes & 759 & 4 & 527.0 & $\mathrm{p}=0.62$ \\
\hline No & 1420 & 10 & 704.2 & \\
\hline
\end{tabular}

Source: Authors (2021).

It was found that there was an association between positive cases in the rapid survey test in participants with rheumatic diseases $(\mathrm{p}=0.05)$. Although hypertensive, smokers and people with lung diseases have a higher prevalence of positive cases, no significant association was found. In relation to the elderly, the highest prevalence was negative cases, even though there was no statistically significant difference (Table 3).

Table 3 - Evaluation of aggravating factors, comorbidities and associations based on the positive cases of the rapid test for COVID 19, in the municipality of Chapecó, SC, June, July and August 2020.

\begin{tabular}{|c|c|c|c|c|}
\hline Profile & $\begin{array}{l}\text { Count } \\
\text { (n) }\end{array}$ & Positives & $\begin{array}{l}\text { Prevalence } \\
\text { (/100 thousand) }\end{array}$ & $\begin{array}{l}\text { Significance (Chi- } \\
\text { square) }\end{array}$ \\
\hline \multicolumn{5}{|c|}{ Smoking } \\
\hline Yes & 138 & 1 & 724.6 & $\mathrm{p}=0.90$ \\
\hline No & 2041 & 13 & 636.9 & \\
\hline \multicolumn{5}{|c|}{ Elderly (above 60 years old) } \\
\hline Yes & 212 & 1 & 471.7 & $\mathrm{p}=0.74$ \\
\hline No & 1967 & 13 & 660.9 & \\
\hline \multicolumn{5}{|c|}{ Pregnant } \\
\hline Yes & 17 & 0 & 0.0 & $\mathrm{p}=0.74$ \\
\hline
\end{tabular}


Research, Society and Development, v. 10, n. 9, e30710917996, 2021

(CC BY 4.0) | ISSN 2525-3409 | DOI: http://dx.doi.org/10.33448/rsd-v10i9.17996

\begin{tabular}{|c|c|c|c|c|}
\hline No & 2162 & 14 & 647.5 & \\
\hline \multicolumn{5}{|c|}{ Hypertensive } \\
\hline Yes & 320 & 3 & 937.5 & $\mathrm{p}=0.47$ \\
\hline No & 1859 & 11 & 591.7 & \\
\hline \multicolumn{5}{|c|}{ Diabetic } \\
\hline Yes & 94 & 0 & 0.0 & $\mathrm{p}=0.42$ \\
\hline No & 2085 & 14 & 671.5 & \\
\hline \multicolumn{5}{|c|}{ Pulmonary disease } \\
\hline Yes & 130 & 1 & 769.2 & $\mathrm{p}=0.85$ \\
\hline No & 2049 & 13 & 634.5 & \\
\hline \multicolumn{5}{|c|}{ Cardiac disease } \\
\hline Yes & 101 & 0 & 0.0 & $\mathrm{p}=0.41$ \\
\hline No & 2078 & 14 & 673.7 & \\
\hline \multicolumn{5}{|c|}{ Renal disease } \\
\hline Yes & 48 & 0 & 0.0 & $\mathrm{p}=0.57$ \\
\hline No & 2131 & 14 & 657.0 & \\
\hline \multicolumn{5}{|c|}{ Hepatic disease } \\
\hline Yes & 44 & 0 & 0.0 & $\mathrm{p}=0.59$ \\
\hline No & 2135 & 14 & 655.7 & \\
\hline \multicolumn{5}{|c|}{ Transplanted } \\
\hline Yes & 2 & 0 & 0.0 & $\mathrm{p}=0.91$ \\
\hline No & 2177 & 14 & 643.1 & \\
\hline \multicolumn{5}{|c|}{ Rheumatic disease } \\
\hline Yes & 28 & 1 & 3571.4 & $\mathrm{p}=0.05$ \\
\hline No & 2151 & 13 & 604.4 & \\
\hline \multicolumn{5}{|c|}{ HIV positive } \\
\hline Yes & 2 & 0 & 0.0 & $\mathrm{p}=0.91$ \\
\hline No & 2177 & 14 & 643.1 & \\
\hline \multicolumn{5}{|c|}{ Cancer diagnosis } \\
\hline Yes & 19 & 0 & 0.0 & $\mathrm{p}=0.72$ \\
\hline No & 2160 & 14 & 648.1 & \\
\hline \multicolumn{5}{|c|}{ Chemotherapy } \\
\hline Yes & 6 & 0 & 0.0 & $\mathrm{p}=0.84$ \\
\hline No & 2173 & 14 & 644.3 & \\
\hline
\end{tabular}




\begin{tabular}{|c|c|c|c|c|}
\hline \multicolumn{5}{|c|}{ Undergo major surgery in the last 30 days } \\
\hline Yes & 11 & 0 & 0.0 & $\mathrm{p}=0.79$ \\
\hline No & 2168 & 14 & 645.8 & \\
\hline \multicolumn{5}{|c|}{ Another illness or use of continuous medication } \\
\hline Yes & 672 & 4 & 595.2 & $\mathrm{p}=0.93$ \\
\hline No & 1597 & 10 & 626.2 & \\
\hline
\end{tabular}

Source: Authors (2021).

\section{Discussion}

The present study evaluated the seroprevalence of SARS-CoV-2 infection in the municipality of Chapecó, Santa Catarina, using the ONE STEP COVID-2019 TEST® rapid test. In all, 2,179 people were tested and from these, 14 had a positive rapid test for COVID-19. There was a similar prevalence among men and women, a fact corroborated in the study by Callender et al. (2020) which points out that there are no major differences between sex when examining the absolute number of COVID-19 cases (Callender et al., 2020).

Regarding the rapid test used in the present study, the sensitivity and specificity, according to the test package insert, are $86 \%$ and $99 \%$, respectively, if applied in the manner and within the established period. In a study by Cota et al. (2020), in which the accuracy and performance of rapid tests applied in studies in Brazil were analyzed, it was observed that the test in question showed $71.7 \%$ sensitivity and, after 7 days symptoms $79.7 \%$, with $100 \%$ specificity, with global accuracy of $88.6 \%$. Still, with less than 7 days of symptoms, the sensitivity of the test was $24 \%$ (Cota et al., 2020).

Among the variables contained in Table 1, the significant association with a positive rapid test was living with five or more people in the same household ( $\mathrm{p}<0.001$ ). In parallel to this, it was shown that families with three or more children had a higher prevalence of positive cases. Such findings are in line with what is widely available in the literature, namely the study by Song et al. (2020), which reports the rapid transmissibility of COVID-19 in the form of family groups (Song et al., 2020).

This study also mentions that, although the infection rate is high within the family group, the manifestations of the disease, the latent and elimination period of the virus varied greatly. Therefore, they recommend rigorously testing contacts, even during the symptom-free phase, and considering whether viral spread has ceased before interrupting isolation measures (Song et al., 2020).

In this sense, the results of this research corroborate Song et al. (2020): the incidence of positive cases in participants with someone who is sick at home or who was already ill was almost twice as much as in participants with healthy home contacts (Table 2). The increased prevalence in these cases can be explained by the fact that the epidemics of respiratory infections are more efficient and aggressive in the home space, as well as in other closed places where people are crowded (Song et al., 2020; Câmara, Câmara \& Moreno, 2020).

Notwithstanding this, several models of home detachment have been established, encouraged and tested in different studies. For example, Garcia Filho (2020), in his study of simulation of distance measures between households and transmission of COVID-19 by close contacts, concluded that home transmission should be rigorously evaluated, just like community transmission. It can be seen that although a great focus is given to social distance from home, special attention should be directed to encouraging measures of distance from home that are able to further reduce the rates of positive cases of COVID-19 (Garcia Filho, 2020). 
As for education, the present study showed a higher incidence of COVID-19 in people who have incomplete higher education (undergraduate) and postgraduate studies. The studies published to date do not discuss the educational level of those affected by the disease (Ahn et al., 2020; Hallal et al., 2020; Ge et al., 2020; Rothan \& Byrareddy, 2020). However, it is believed that this level of education may be related to workers in essential services who were not interrupted during periods of greater control of social isolation (Coroiu et al., 2020).

Regarding the incidence, the results obtained in the present study demonstrated that COVID-19 was higher in health professionals or students. In Brazil, these professionals have faced the challenges of the pandemic since its inception, being constantly exposed to the virus. Studies carried out in several countries show a high incidence rate of the disease in this population (Huston et al., 2020; Nienhaus \& Hod, 2020; Sommerstein et al., 2020). Hospitals and health centers in Brazil face overcrowding and a shortage of professionals to meet the demand. Even with the use of masks and personal protective equipment, health professionals have been widely infected (Sommerstein et al., 2020), a trend corroborated by the present study.

When comparing positive and negative cases with occupation, it was found that the incidence of cases doubled in people with formal jobs, compared to those who do not have this employment relationship. This shows that people with a formal contract were more exposed to the virus. A survey carried out by "Datafolha" (Datafolha, 2018), showed that a significant proportion of the Brazilian population was unable to stop working or cannot work at home (Datafolha, 2018).

This fact corroborates other data analyzed in this study: the incidence of positives was higher in people who continued working or studying outside the home or who left their homes for physical activity. This result is in line with studies that advocate measures of social isolation to contain the pandemic, even though they know that a quarter of respondents reported the need to leave home for work or another activity (Aquino et al., 2020).

As for contact with people diagnosed with COVID-19 or people with symptoms of the disease in the last two weeks, there was a statistically significant difference between positive cases and negative ones (Table 2). This data demonstrates the social behavior associated with the means of transmission of SARS-Cov-2, since this virus exhibits a high transmission capacity (Chan et al., 2010). Another important point is that asymptomatic patients can be contagious, even though there is no significant incidence of asymptomatic positives in the present study (Rothe et al., 2020).

Another point to be highlighted is the period related to the person's contact with SARS-CoV-2 and the onset of symptoms. This study demonstrated a higher incidence in those who traveled two weeks before participating in the study. This fact is corroborated by the viral incubation time since this period takes about seven days on average. Although it is still not entirely clear how easily the virus can be transmitted from person to person, it is known that measures of social isolation have been effective in controlling transmission and, consequently, controlling the pandemic by SARS-Cov-2 (Awadasseid et al., 2020; Chan et al., 2020).

Regarding pre-existing comorbidities, people already diagnosed with chronic disease are at a higher risk of having complications due to COVID-19. It is noteworthy that comorbidities are commonly associated with each other, such as hypertension, diabetes and obesity, and in these cases the risk of worsening is increased (Callender et al., 2020). In a systematic review, it was observed that the levels of diabetes, hypertension and cholesterol have an apparent relationship with the severity of COVID-19. Other comorbidities, such as cancer, kidney disease and stroke, should be further studied to determine such a relationship (Zaki, Alashwal \& Ibrahim, 2020).

In the present study, with the exception of the association between positive cases in the rapid test and patients with rheumatic diseases, in the other analyzed comorbidities there was no statistically significant association. It should be noted that the increased risk for the development of COVID-19 and risk factors for the worsening of the disease are different conditions. 
A meta-analysis revealed that there is no correlation between the increased risk of COVID-19 in people with liver disease, malignancy or kidney disease (Wang et al., 2020). In this same perspective, the study by Engin, Engin \& Engin (2020) revealed that obese people, smokers or those who are exposed to air pollution with greater intensity have an increased risk of acquiring COVID-19, since they share the underlying pathophysiology related to renin angiotensin system (increased angiotensin II compared to healthy people) in SARS-CoV-2 infection (Engin, Engin \& Engin, 2020).

With regard to age, Callender et al. (2020), in their review, point out that individuals aged 60 years or more are more likely to develop the disease in a severe way and have a higher mortality rate. However, age is not a major risk factor for acquiring the infection. The results of this study demonstrate that being 60 years or older is not associated with a positive rapid test for COVID-19, on the contrary, the highest prevalence was of negative cases. This finding can be explained by the fact that the policies of social distancing emphasized, above all, the elderly population.

\section{Final Considerations}

Although the test used in the present study underestimated the true coronavirus infection rates in the municipality of Chapecó, our study demonstrated associations between the clinical and epidemiological behavior of COVID-19 in the city in question. It also showed the necessity for further studies in the area, as well as the importance of paying attention to the accuracy of the new rapid tests for COVID-19 and correlating the infection rates detected by rapid tests with the diagnoses performed by the gold standard, Polymerase Chain Reaction test (PCR).

The rapid test for Covid 19 represents a mechanism for defining actions to control the pandemic. It proved to be an important tool for government actions before the arrival of the vaccine. Despite the low sensitivity and specificity, it proved to be an important adjuvant in monitoring the disease.

\section{Acknowledgments}

The authors thank the funders, the medical students from UFFS and Unochapecó that recruited the participants and the study participants.

\section{References}

Ahn, D. G., Shin, H. J., Kim, M. H., Lee, S., Kim, H. S., Myoung, J., Kim, B. T., \& Kim, S. J. (2020). Current Status of Epidemiology, Diagnosis, Therapeutics, and Vaccines for Novel Coronavirus Disease 2019 (COVID-19). Journal of Microbiology and Biotechnology. 30(3), 313-324.

Aquino, E. M. L., Silveira, I. H., Pescarini, J. M., Aquino, R., Souza-Filho, J. A., Rocha, A. S., Ferreira, A., Victor, A., Teixeira, C., Machado, D. B., Paixão, E., Alves, F. F. O., Pilecco, F., Menezes, G, Gabrielli, L., Leite, L., Almeida, M. C. C., Ortelan, N., Fernandes, Q. H. R. F., Ortiz, T. J. F., Palmeira, R. N., Pinto Junior, E. P., Aragão, E., Souza, L. E. P. F., Netto, M. B., Teixeira, M. G., Barreto, M. L., Ichihara, M. Y., \& Lima, R. T. R. S. (2020). Social distancing measures to control the COVID-19 pandemic: potential impacts and challenges in Brazil. Medidas de distanciamento social no controle da pandemia de COVID-19: potenciais impactos e desafios no Brasil. Ciencia \& Saúde Coletiva. 25(suppl 1), 2423-2446.

Awadasseid, A., Wu, Y., Tanaka, Y., \& Zhang, W. (2020). Initial success in the identification and management of the coronavirus disease 2019 (covid-19) indicates human-to-human transmission in Wuhan, China. International journal of biological sciences. 16(11), 1846-1860.

Bambra, C., Riordan, R., Ford, J., \& Matthews, F. (2020). A pandemia de covid-19 e desigualdades em saúde. Journal of epidemiology and community health. 74 (11), 964-968.

Callender, L. A., Curran, M., Bates, S. M., Mairesse, M., Weigandt, J., \& Betts, C. J. (2020). The Impact of Pre-existing Comorbidities and Therapeutic Interventions on COVID-19. Frontiers in Immunology. 11, 1-16.

Câmara, F. P., Câmara, D. C. P., \& Moreno, M. (2020). Contágio e virulência: covid-19 e a próxima pandemia. Brazilian Journal of Health Review. 3(5),13353-13357.

Carvalho, M. S., Lima, L. D., \& Coeli, C. (2020). Ciência em tempos de pandemia. Cafajeste. Saúde Pública. 36(4), 1-3.

Coroiu, A., Moran, C., Campbell, T., \& Geller, A. C. (2020). Barriers and facilitators of adherence to social distancing recommendations during COVID-19 among a large international sample of adults. PLoS One. 15(10), e0239795. 
Chan, J. F., Yuan, S., Kok, K. H., Kai-Wang, K., Chu, H., Yang, J., Xing, F., Liu, J., Chik-Yan, C., Poon, R. W. S., Tsoi, H. W., Lo, S. K. F., Chan, K. H., Poon, V. K. M., Chan, W. M., Ip, J. D., Cai, J. P., Cheng, V, C. C., Chen, H., Hui, C. K. M., \& Yuen, K. Y. (2020). A familial cluster of pneumonia associated with the 2019 novel coronavirus indicating person-to-person transmission: a study of a family cluster. Lancet. 395(10223), 514-523.

Cota, G., Freire, M. L., de Souza, C. S., Pedras, M. J., Saliba, J. W., Faria, V., Alves, L. L., Rabello, A., \& Avelar, D. M. (2020). Diagnostic performance of commercially available COVID-19 serology tests in Brazil. International Journal of Infectious Diseases. 101,382-390.

Datafolha. (2020). Opinião sobre a pandemia do Coronavírus: comportamento da população e medidas do governo. Datafolha. http://media.folha.uol.com.br/datafolha/2020/04/06/6c9855d692b869f13c5d83c421568342hb.pdf.

Engin, A. B., Engin, E. D., \& Engin, A. (2020). Two important controversial risk factors in sars-cov-2 infection: obesity and smoking. Environmental toxicology and pharmacology. 78, 103411.

Garcia Filho, C. (2020). Simulação de medidas de distanciamento intradomiciliar e transmissão do SARS-CoV-2 por contatos próximos. Cad de Saúde Pública. 36(5).

Ge, H., Wang, X., Yuan, X., Xiao, G., Wang, C., Deng, T., Yuan, Q., \& Xiao, X. (2020). The epidemiology and clinical information about COVID-19. European journal of clinical microbiology and infectious diseases. 39(6), 1011-1019.

Hallal, P. C., Hartwig, F. P., Horta, B. L., Silveira, M. F., Struchiner, C. J., Vidaletti, L. P., Neumann, N. A., Pellanda, L. C., Dellagostin, O. A., Burattini, M. N., Victora, G. D., Menezes, A. M. B., Barros, F. C., Barros, A. J. D., \& Victora, C. G. (2020). SARS-CoV-2 antibody prevalence in Brazil: results from two successive nationwide serological household surveys. Lancet Global Health. 8(11), 1390-1398.

Huston, P., Campbell, J., Russell, G., Goodyear-Smith, F., Phillips, R. L., Weel, C., \& Hogg, W. (2020). COVID-19 and primary care in six countries. BJGP Open. 4(4), bjgpopen20X101128.

Koche, J. C. (2011). Fundamentos de metodologia científica. Petrópolis: Vozes.

Ludke, M. \& Andre, M. E . D. A. (2013). Pesquisas em educação: uma abordagem qualitativa. E.P.U.

Nienhaus, A., \& Hod, R. (2020). COVID-19 among Health Workers in Germany and Malaysia. International Journal of Environmental Research and Public Health. 17(13), 4881.

Petry, P. (2020). Epidemiologia Em Tempos Da Pandemia Covid-19. Saberes Plurais: Educação na Saúde. 4(1),6-10.

Rothan, H. A., \& Byrareddy, S. N. (2020). The epidemiology and pathogenesis of coronavirus disease (COVID-19) outbreak. Journal of Autoimmunity. 109, 102433.

Rothe, C., Schunk, M., Sothmann, P., Bretzel, G., Froeschl, G., Wallrauch, C., Zimmer, T., Thiel, V., Janke, C., Guggemos, W., Seilmaier, M., Drosten, C., Vollmar, P., Zwirglmaier, K., Zange, S., Wölfel, R., \& Hoelscher, M. (2020). Transmission of 2019-nCoV Infection from an Asymptomatic Contact in Germany. New England Journal of Medicine. 382(10), 970-971.

Sommerstein, R., Fux, C. A., Vuichard-Gysin, D., Abbas, M., Marschall, J., Balmelli, C., Troillet, N., Harbarth, S., \& Schlegel, M., Widmer, A. (2020). Risk of SARS-CoV-2 transmission by aerosols, the rational use of masks, and protection of healthcare workers from COVID-19. Antimicrobial Resistance \& Infection Control. 9(1), 100

Song, R., Han, B., Song, M., Wang, L., Conlon, C. P., Dong, T., Tian, D., Zhang, W., Chen, Z., Zhang, F., Shi, M., \& Li, X. (2020). Clinical and epidemiological features of COVID-19 family clusters in Beijing, China. Journal of Infection. 81(2), 26-30.

Wang, B., Li, R., Lu, Z., Huang, Y. (2020). Does comorbidity increase the risk of patients with COVID-19: evidence from meta-analysis. Aging (Albany NY). 12(7), 6049-6057.

Who. (2020). World Health Organization. Novel coronavirus situation report-106. World Health Organization. https://www.who.int/docs/defaultsource/coronaviruse/situation-reports/20200505covid-19-sitrep-106.pdf?sfvrsn=47090f63_2.

Yin, R. K. (2015). O estudo de caso. Bookman.

Zaki, N., Alashwal, H., \& Ibrahim S. (2020). Association of hypertension, diabetes, stroke, cancer, kidney disease, and high-cholesterol with COVID-19 disease severity and fatality: A systematic review. Diabetes, Metabolic Syndrome and Obesity: Targets and Therapy. 14(5), 1133-1142. 